\title{
Multiple papillary fibroelastomas as a cause of recurrent syncope
}

\author{
Živojin S. Jonjev, MD, PhD, Vladimir Torbica, MD, and Renata Mojašević, MD, Sremska Kamenica, Serbia
}

Papillary fibroelastoma $(\mathrm{PF})$ is a rare cardiac tumor that is usually complicated by unclear embolic events. ${ }^{1}$ Most cases have been diagnosed postmortem at autopsy; however, improved imaging modalities and routine echocardiographic examinations have demonstrated that the true incidence of this phenomenon is underestimated. ${ }^{2}$ Multiple PFs are not described in the recently published literature, so we report the case of a woman, free of traditional cardiac risk factors, who required emergency surgery because of multiple PFs complicated by recurrent syncope.

\section{CLINICAL SUMMARY}

A 66-year-old white woman was transferred from an outside hospital with a documented aortic valve mass. Before admission, the patient had a transient cerebral ischemic event with loss of consciousness, collapse, and consequent front head laceration. Medical history included a previous episode of syncope 4 weeks before admission, at home. Chest roentgenography demonstrated borderline size heart, and electrocardiography confirmed normal sinus rhythm (heart rate 75 beats/min). Transthoracic echocardiography revealed normal left ventricular systolic function (ejection fraction $61 \%$ ) and the presence of multiple echogenic masses on the aortic valve. Transesophageal echocardiography confirmed 3 individual mobile masses $(2.0 \times 1.5 \mathrm{~cm})$. Each mass was attached separately to the aortic cusp by a short pedicle and floated in both directions with respect to the aortic valve (Figure 1). Coronary angiography showed no atherosclerotic changes, and the patient was scheduled for emergency heart surgery to reduce the risk of early recurrence of embolic events.

The heart was arrested, and a standard on-pump procedure was carried out. The transaortic approach to aortic valve revealed 3 individual tumor masses with minor thrombus incorporated on the tumor surface (Figure 2). A significant fibrosis of the surrounding valve tissue was found, so the tumor was resected together with the aortic valve, which was replaced with a mechanical bileaflet prosthesis.

\footnotetext{
From the Clinic of Cardiovascular Surgery, Institute for Cardiovascular Diseases of Vojvodina, University in Novi Sad, Sremska Kamenica, Serbia.

Disclosures: Authors have nothing to disclose with regard to commercial support.

Received for publication Dec 10, 2012; accepted for publication Jan 11, 2013; available ahead of print Feb 11, 2013.

Address for reprints: Živojin S. Jonjev, MD, PhD, Clinic of Cardiovascular Surgery,

Institute for Cardiovascular Diseases of Vojvodina, Institutski put 4, 21204

Sremska Kamenica, Serbia (E-mail: jonjevz@lycos.com).

J Thorac Cardiovasc Surg 2013;145:e51-2

$0022-5223 / \$ 36.00$

Copyright (c) 2013 by The American Association for Thoracic Surgery

http://dx.doi.org/10.1016/j.jtcvs.2013.01.008
}

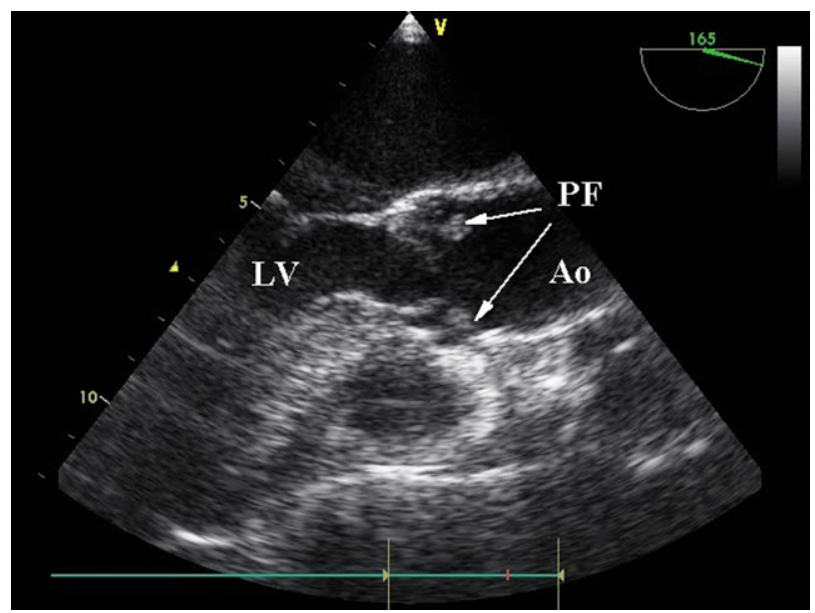

FIGURE 1. Intraoperative transesophageal echocardiography before cardiac arrest. Arrows indicate tumor masses attached to the aortic valve. $A o$, Aorta; $L V$, left ventricle; $P F$, papillary fibroelastoma.

Histologic examination of the specimen confirmed cardiac PF. The postoperative course of the patient was uneventful, and she was discharged 6 days after surgery.

\section{DISCUSSION}

Cardiac PF is a rare primary benign tumor. It is produced from the endocardial components (elastic, and fibrous tissue) assembled in a mass and attached to the endocardium by a pedicle. ${ }^{1}$ Theoretically, PF could arise from any endocardial surface; however, it is frequently seen on the cardiac valves. Multiple cardiac PFs are atypical, and such reports

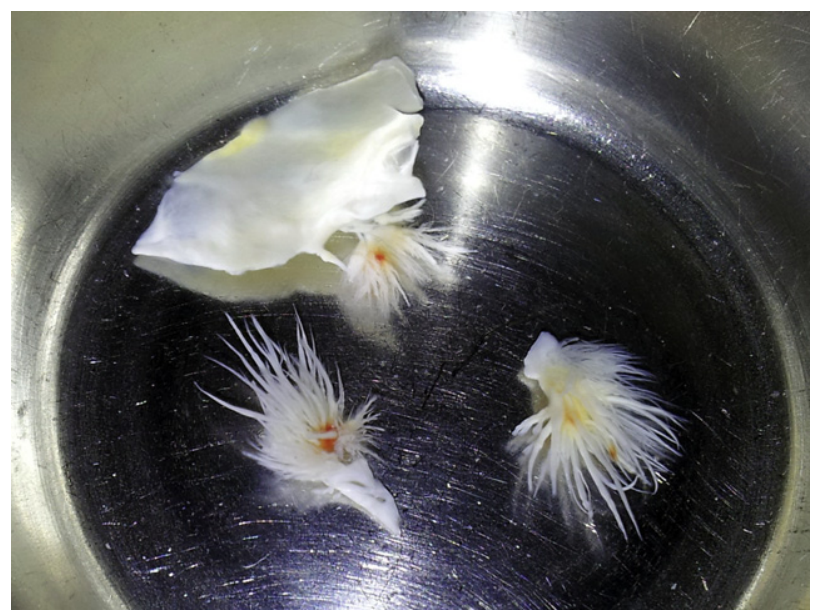

FIGURE 2. Gross view of the excised papillary masses with microthrombi incorporated on the tumor surface. 
are rarely found in the literature during the last 2 decades. PFs exhibit no sex association and are most commonly seen between the third and fifth decades of life. ${ }^{1,3}$ Historically, cardiac PF has been an incidental autopsy finding $(<1 \%)$ with undetermined clinical significance. At present, thanks to modern echocardiography, such tumors are relatively easy to detect, and their incidence and clinical importance seems to have been underestimated. PF in adult is usually misdiagnosed as valve vegetations or tumor mass because of similar echocardiographic visualization., ${ }^{2,3}$ Transesophageal echocardiography is established as the optimal imaging technique for PF diagnosis, with cardiac catheterization considered only to investigate associated cardiac malformations.

Symptomatic cases with embolic complications, such as stroke, suggest that cardiac PF should be considered a potentially dangerous disease with preventable complications. ${ }^{2}$ Complete surgical excision should be performed as early as possible to reduce the risk of early recurrence of embolic events. A thrombus found on the tumor surface is an important clinical finding that supports the theory that recurrent strokes could be a consequence of PF embolization or of damage along the endothelial surface and subsequent thrombosis. ${ }^{1,4}$ When a valve-sparing procedure is not possible, as in our case, surgical valve replacement should be an option, not only to correct valve dysfunction but to reduce the potential for recurrence, as reported by Lawton and associates. $^{5}$

In conclusion, we report a very rare case of multiple aortic valve $\mathrm{PF}$ as a cause of recurrent syncope in an adult. Urgent surgical excision of PF tissue had a favorable outcome. The patient survived the operation without postoperative complications and was well and without recurrence 6 months after surgery.

\section{References}

1. Kuwashiro T, Toyoda K, Otsubo R, Ishibashi-Ueda H, Tagusari O, Minematsu K. Cardiac papillary fibroelastoma as a cause of embolic stroke: ultrasound and a histopathological characteristics. Intern Med. 2009;48:77-80.

2. Howard RA, Aldea GS, Shapira OM, Kasznica JM, Davidoff R. Papillary fibroelastoma: increasing recognition of a surgical disease. Ann Thorac Surg. 1999;68: 1881-5.

3. Tsukube T, Ataka K, Taniguchi T, Yokoyama M, Hanioka K. Papillary fibroelastoma of the left atrial appendage: echocardiographic findings. Ann Thorac Surg. 2000;70:1416-7.

4. Grinda JM, Couetil JP, Chauvaud S, D'Attellis N, Berrebi A, Fabiani JN, et al. Cardiac valve papillary fibroelastoma: surgical excision for revealed or potential embolizaton. J Thorac Cardiovasc Surg. 1999;117:106-10.

5. Anastacio MM, Moon MR, Damiano RJ Jr, Pasque MK, Maniar HS, Lawton JS Surgical experience with cardiac papillary fibroelastoma over a 15-year period. Ann Thorac Surg. 2012;94:537-41. 